Contents available at: Sri Lanka Journals Online

\title{
Biochar Based Slow-Release Urea Fertilizer: Production and Assessing the Effects on Growth of Lowland Rice and Nitrogen Dynamics in an Alfisol
}

\author{
M.K.N.W. Jayarathna ${ }^{1}$, R.S. Dharmakeerthi ${ }^{1^{*}}$ and W.M.U.K. Rathnayaka ${ }^{2}$ \\ ${ }^{1}$ Department of Soil Science, Faculty of Agriculture, University of Peradeniya, Peradeniya, Sri Lanka. \\ ${ }^{2}$ Rice Research and Development Institute, Bathalegoda, Sri Lanka.
}

\section{ARTICLE INFO}

Article history:

Received: 29 July 2020

Revised version received: 3 October 2020

Accepted: 17 January 2021

Available online: 1 April 2021

\section{Keywords:}

Biochar

Nitrogen use efficiency

Rice

Sawdust

Slow-release fertilizer

Tea waste

\section{Citation:}

Jayarathna, M.K.N.W., Dharmakeerthi, R.S., and Rathnayaka, W.M.U.K. (2021). Biochar based slow-release urea fertilizer: Production and assessing the effects on growth of lowland rice and nitrogen dynamics in an Alfisol. Tropical Agricultural Research, 32(2): 168-178.

DOI: http://doi.org/10.4038/tar.v32i2.8464

Jayarathna, M.K.N.W.

https://orcid.org/0000-0001-7124-3868

\section{ABSTRACT}

Use efficiency of $\mathrm{N}$ fertilizers in lowland rice cultivation is very low. Biochar can be used to modify the $\mathrm{N}$ releasing rates of fertilizers and increase their efficiency. Maximum amount of urea that can be intercalated into biochar (BC) and the effects of biochar based slow-release urea fertilizer (SRF) on soil solution $\mathrm{N}$ contents and growth of rice (Oryza sativa) were investigated. Two feedstock materials (sawdust and tea waste) were slow pyrolysed at $500^{\circ} \mathrm{C}$ to produce $\mathrm{BC}$ and $\mathrm{N}$ were intercalated into $\mathrm{BC}$ using urea solutions with seven concentrations (U1=0\% $<\mathrm{U} 2<\mathrm{U} 3<\mathrm{U} 4<\mathrm{U} 5<\mathrm{U} 6<\mathrm{U} 7=100 \% \quad \mathrm{w} / \mathrm{v})$. The maximum intercalated $\mathrm{N}$ contents in sawdust $\mathrm{BC}$ and tea waste $\mathrm{BC}$ were $28 \%$ and $22 \%$, respectively. Five treatments: two SRFs at 17.25 mg $\mathrm{N} \mathrm{kg}^{-1}$ soil (75\% recommended $\mathrm{N}$ ) and three urea levels (0, 75 , and $100 \% \mathrm{~N}$ ) were applied to rice plants (Bg 251) in a pot experiment. Application of SRF significantly improved the greenness and growth of rice plants when compared with $0 \% \mathrm{~N}$ control and were comparable with $100 \%$ urea-N treatment. The apparent recovery of $\mathrm{N}$ (ARN) was significantly $(\mathrm{p}<0.05)$ improved in SRFs (60-71\%) compared to urea only treatments (38-52\%). Nitrate-N contents in soil solution were not significantly different $(\mathrm{p}<0.05)$ among treatments while $\mathrm{NH}^{+}-\mathrm{N}$ content in $100 \%$ urea treatment was significantly $(p<0.05)$ higher throughout. Based on urea intercalation efficiency and the ARN, we concluded that SRF made using sawdust biochar is having a higher potential than SRF made using tea waste biochar to improve the efficiency of urea in lowland rice cultivation.

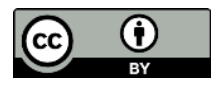

\footnotetext{
* Corresponding author: dharmakeerthirs@pdn.ac.lk
} 


\section{INTRODUCTION}

Rice cultivation in Sri Lanka uses about $60 \%$ of the urea imported to the country and the nitrogen use efficiency (NUE) of added urea is less than $30 \%$ in rice growing soils (Sirisena et al., 2013). The unutilized nitrogen $(\mathrm{N})$ could possibly cause a high risk of environmental pollution and an economic loss. Recently, the United Nations Environment Program set a target to halve N waste in Sri Lanka by year 2030 through the Colombo Declaration (UN, 2019). Hence, investigations on increasing NUE is a timely requirement to reduce $\mathrm{N}$ fertilizer usage while increasing or maintaining a high crop productivity.

There are many approaches to address this " $\mathrm{N}$ dilemma", the trade-off between food production and $\mathrm{N}$ pollution. Adapting best management practices, resource conserving agricultural technology with integrated farming and intercropping, application of nitrification inhibitors and urease inhibitors, introduction of improved varieties and use of efficient fertilizer technologies are few such approaches commonly used (Montemurro and Diacono, 2016). Although these practices have shown to be agronomically effective, most farmers are reluctant to adopt them due to lack of resources and high costs incurred for materials and labour. Hence, there is a necessity to introduce technologies as adoptable and costeffective products in soil fertility management.

An alternative technology to improve nitrogen use efficiency while reducing the environmental hazards is to use controlled release or slow-release fertilizers (Bockman and Olfs, 1998; Peoples et al., 1995). Slow release fertilizer (SRF) technologies can be classified as inorganic low-solubility compounds, fertilizers with physical barriers, and organic low-solubility compounds (Shaviv, 2000). In Sri Lanka, Kottegoda et al. (2017) has developed urea-hydroxyapatite (HA) nanohybrid to reduce the solubility of urea by incorporating into a matrix of HA nano particles. The rate of release of $\mathrm{N}$ of the HA nano hybrid is 12 times slower than the pure urea. However, the cost of this slow release fertilizer is expected to be very high. After reviewing literature related to SRF, Shaviv (2000) suggested that the priority need in future research is to develop new concepts for preparing more cost-effective SRFs.

Biochar (BC) has unique characters such as having a massive micro pore structure, high surface area and charged surfaces (Lehmann, 2007). It can be made using organic waste materials under controlled pyrolysis conditions and locally BC has been made from rice husk, corn cobs, coconut husk, saw dust and rubber wood (Dharmakeerthi et al., 2012; Munasinghe et al., 2018). Number of studies have been conducted on using $\mathrm{BC}$ in fertilizer $\mathrm{N}$ management. In many studies $\mathrm{BC}$ has been used as a substrate to regulate the $\mathrm{N}$ release from urea (Chunxue et al., 2015; González et al., 2015; Manikandan and Subramanian, 2013; Rose et al., 2016) and different methods have been used to combine urea and $\mathrm{BC}$ to produce a successful composite to enhance the $\mathrm{N}$ use efficiency.

González et al. (2015) encapsulated urea into BC using biodegradable polymers as encapsulating agents. Ethyl cellulose has shown a better performance as an encapsulating agent, where total N leaching was lower compared with fertilizer urea. Studies by Manikandan and Subramanian (2013) on intercalation of urea into biochar reported that the slow diffusion has loaded $\mathrm{N}$ into micro pores in the BC structure and desorption pattern of $\mathrm{N}$ indicated that the biochar fortified with urea had the least release rates of $\mathrm{N}$. After observing the changes in ammonium and nitrate levels in the soil, Dimin et al. (2014) found that the hydrolysis of urea in the impregnated samples are slower than the urea only samples. Some part of $\mathrm{N}$ can be immobilized by the adsorption of urea or hydrolysed ammonium to the lignite matrix of $\mathrm{BC}$ (Rose et al., 2016). The BC based nitrogen fertilizer formulated with urea has a longer residual effect compared to the exclusive application of urea and this effect is related to the $\mathrm{N}$ release pattern, which emphasizes the potential of this technology in the formulation of slow release $\mathrm{N}$ fertilizers (De Carvalho et al., 2019).

Biochar not only reduces $\mathrm{N}$ wastage but also helps to reduce some environmental risks associated with lowland rice cultivation (Yin et al., 2016; Cui et al., 2011). Cadmium uptake by rice plants is a significant concern (He et al., 2017) and the reduction of Cd uptake in rice plants by 50 percent from contaminated soil has been observed after addition of BC to the soil. He et al. (2017) showed that biochar behaves as a sorbent material by adsorbing soil Cd to the biochar surfaces. Kim et al. (2017) argues that BC based SRF are highly recommended for rice because of the $B C$ reduces the methanogenisis by soil aeration while maximizes the rice yield. Clark et al. (2019) found that $\mathrm{BC}$ increases long-term nitrogen storage in agricultural soils. Also the overall $\mathrm{N}_{2} \mathrm{O}$ emission is reduced by adding BC to soil (Yoo et al., 2018).

Although BC has been used to produce SRF using simple technologies (Manikandan and Subramanian, 2013, Gamage et al., 2012), their 
significance in reducing $\mathrm{N}$ waste needs further investigations. Moreover, the effects of BC based slow release urea fertilizer on growth of rice plant and $\mathrm{N}$ availability has not so far been studied under eco-physiological conditions in Sri Lanka. The present study was conducted based on the hypothesis that $\mathrm{BC}$ can be used to produce a slow release urea fertilizer that could increase NUE and growth of rice plants in lowland rice cultivations. Therefore, the objectives of this study were to produce a slow-release urea fertilizer using biochar produced from locally available organic waste and to assess the effects of these biochar based SRFs on growth of rice plants, $\mathrm{N}$ dynamics and NUE in a rice growing Alfisol of Sri Lanka.

\section{METHODOLOGY}

\section{Production and characterization of SRF}

Two feedstock materials (sawdust and tea waste) were slow pyrolysed separately at $500^{\circ} \mathrm{C}$ using closed containers in a muffle furnace to produce two types of $\mathrm{BC}$ and they were characterized for basic chemical parameters: $\mathrm{pH}$ and EC (Enders et al., 2012), total organic $C$ and total $N$ using a $C N$ analyzer (SKALAR Primacs SNC100), available P after extracting with $0.5 \mathrm{M} \mathrm{NaHCO}_{3}$ (Olsen and Sommers, 1982) and determined by spectrophotometry (SHIMADZU UV-1601) and available $\mathrm{K}, \mathrm{Ca}$ and $\mathrm{Mg}$ using Melich III extraction (Mehlich, 1984) and determined by Atomic Absorption Spectrometry (Agilent 200).

Urea was intercalated into the sawdust biochar and tea waste biochar using capillary action. The minimum urea concentration in the solution which gives the maximum intercalation to reduce urea wastage was determined. The two types of $\mathrm{BC}$ $(100 \mathrm{~g})$ were added into $1 \mathrm{~L}$ of urea solutions with seven concentrations $(\mathrm{U} 1<\mathrm{U} 2<\mathrm{U} 3<\mathrm{U} 4<\mathrm{U} 5<\mathrm{U} 6<\mathrm{U} 7$ ranging from 0 to $100 \% \mathrm{w} / \mathrm{v}$ ) and left overnight. Urea intercalated $\mathrm{BC}$ were then filtered and rinsed with distilled water to remove excess urea. The urea-biochar composites were dried at $40^{\circ} \mathrm{C}$ and total $\mathrm{N}$ contents were determined using the $\mathrm{CN}$ analyzer. Composites produced using the optimum urea concentration were palatalized using a laboratory scale manual pelletizer. The pellets produced from urea-saw dust biochar and urea-tea waste biochar were called $\mathrm{SRF}_{\mathrm{SD}}$ and $\mathrm{SRF}_{\mathrm{TW}}$, respectively.

A rapid water release test was conducted to determine the $\mathrm{N}$ release rates of the produced SRFs in water as described by Kottegoda et al. (2017). Briefly, $50 \mathrm{mg}$ of $\mathrm{N}$ containing urea or SRF pellets were placed in the middle of an inert fine sand column (10 cm length and $1 \mathrm{~cm}$ diameter) and saturated with distilled water. A volume of water equal to 1.5 times of the porosity of sand was added from the top at different time intervals from 0 to 90 minutes and leachates were collected from the bottom of the columns. Experiment was conducted using three replicates. From the $\mathrm{N}$ concentrations and volume of leachate collected at each time, the total $\mathrm{N}$ released was from urea or SRFs were calculated.

\section{Plant house experiment}

A pot experiment was conducted using a soil collected from $0-15 \mathrm{~cm}$ depth from a $\mathrm{N}$ responsive paddy cultivating filed at the Rice Research and Development Institute, Bathalagoda $\left(7^{\circ} 31^{\prime} 54^{\prime \prime} \mathrm{N}\right.$; $80^{\circ} 26^{\prime} 08^{\prime \prime}$ E). After removing the visible plant residues and debris, well mixed field fresh soil samples were filled into $5 \mathrm{~L}$ pots and packed to a bulk density of $1.4 \mathrm{Mg} \mathrm{m}^{-3}$ and then puddled with excess water. RhizonFlex® soil solution samplers were installed horizontally at $10 \mathrm{~cm}$ depth in each pot. Four paddy seedlings, var. Bg 251, were transplanted in pots and $5 \mathrm{~cm}$ of standing water was maintained throughout the experimental period.

Treatments consisted of No-N (T1), 75\% of recommended $\mathrm{N}$ as urea (T2), $100 \%$ of recommended $\mathrm{N}$ as urea (T3), 75\% recommended $\mathrm{N}$ as $S R F_{S D}$ (T4) and $75 \%$ of recommended $\mathrm{N}$ as $S R F_{T W}$ (T5). As an example, the $100 \% \mathrm{~N}$ treatment received $23 \mathrm{mg}$ of $\mathrm{N} \mathrm{kg}^{-1}$ soil in three top dressings. All management practices other than rate of $\mathrm{N}$ application were same across all treatments and as recommended by the Department of Agriculture. Treatments were arranged in a randomized complete block design (RCBD) under net house conditions with three replicates.

About $20 \mathrm{ml}$ of pore water was sucked out through RhizonFlex $®$ from each pot using a syringe on 1,2 , 3 , 5 days after the first and last $\mathrm{N}$ fertilizer application and analyzed colorimetrically for $\mathrm{NO}_{3}-$ $\mathrm{N}$ (Bremner et al., 1965) and $\mathrm{NH}_{4}{ }^{+}-\mathrm{N}$ (Markus et al., 1985) concentrations. Plant height and the greenness of plants through SPAD meter readings were monitored at 10, 15, 20 day intervals. Shoot dry matter contents, total $\mathrm{N}$ uptake by shoots and grain at the end of the growing period were also measured. Hundred grain weight was measured as the grain yield (at 14\% moisture). In order to assess the use efficiencies of the $\mathrm{N}$ fertilizers used in the experiment, the apparent recovery of $\mathrm{N}$ (ARN) in different treatments was calculated as a fraction of increased $\mathrm{N}$ uptake due to fertilizer application (Fageria and Baligar, 2003) as follows: 
Apperent Recovery of $N(A R N)=\left[\frac{N f-N u}{N a}\right] \times 100 \%$

where, $\mathrm{N}_{\mathrm{f}}$ and $\mathrm{N}_{\mathrm{u}}$ are the $\mathrm{N}$ accumulation in above ground biomass (g) in the fertilized and unfertilized pots, respectively, and $\mathrm{N}_{\mathrm{a}}$ is the quantity of $\mathrm{N}$ applied (g).

\section{Statistical analysis}

After the exploratory data analysis to verify the normality of the data and outliers, analysis of variance was conducted using PROC GLM procedure of the SAS software package (SAS Institute Inc., 2004). Treatment means were separated using the Duncan's multiple range test at a $\mathrm{p}<0.05$ level of significance. Repeated measures analysis was conducted using SPSS software (IBM Corp., 2012) on SPAD meter readings, $\mathrm{NO}_{3}^{-}-\mathrm{N}$, and $\mathrm{NH}_{4}{ }^{+}-\mathrm{N}$ concentrations. The $\mathrm{N}$ treatment were used as the between subject effects and time as the within subject variable. When the sphericity was detected from the Mauchly's test, the GreenhouseGeisser correction was used to test the significance in variables. In instances where time $\times$ treatment interaction effect was significant the Bonferroni correction was employed prior to mean separation.

\section{RESULTS AND DISCUSSION}

\section{Optimum urea concentration for intercalation}

In order to minimize wastage of urea during the SRF production process, the treatment should be capable of obtaining a maximum intercalated urea percentage using a solution having a minimum concentration of urea (Manikandan and Subramanian, 2013). Out of the seven urea concentrations, $\mathrm{N}$ content in sawdust biochar was significantly increased $(\mathrm{p}<0.05)$ from level $\mathrm{U} 1$ to U5 and maintained a similar $\mathrm{N}$ content (around 29\%) thereafter up to the level U7. In tea waste biochar, significantly different maximum $\mathrm{N}$ content (around 22\%) was observed at U6 (Figure 1). Beyond these concentrations, recrystallization of urea, that was not impregnated into the $\mathrm{BC}$, could takes place on the surface of biochar during drying. No further increase of $\mathrm{N}$ content after level U5 for saw dust BC and level U6 for tea waste BC could be due to the saturation of pore spaces with urea. The water holding capacity in biochar made from different feedstock material can be vary due to the variations in porosity, pore structure and hydrophobicity (Gray et al., 2014). At same pyrolysis temperatures $\left(450{ }^{\circ} \mathrm{C}\right)$, the specific surface area of saw dust biochar is higher (10 $\left.\mathrm{m}^{2} / \mathrm{g}\right)$ than that in the tea waste biochar $\left(6.9 \mathrm{~m}^{2} / \mathrm{g}\right)$ (Akgül et al., 2017; Ghani and Silva, 2014). The micro pore structure in $\mathrm{BC}$ is resulted by the escape of volatiles (Ashworth et al., 2014). Hemicellulose in feedstocks will be escaped as it subjected to volatilization during the pyrolysis process (Keech et al., 2005, Watkins et al., 2015) and is higher in sawdust compared to tea wastes (Akgül et al., 2018; Joshua, 2016). Therefore, the reason for having a high intercalated $\mathrm{N}$ contents in saw dust $\mathrm{BC}$ when compared to tea waste $\mathrm{BC}$, especially at higher urea concentrations (Figure 1) could be attributed to the differences in structural properties of the two types of biochar used.

\section{Release of urea-N from SRFs}

According to the rapid water release leaching column experiment, the release of $90 \%$ of intercalated urea-N occurred within first 20-40 minutes (Figure 2). As expected $\mathrm{SRF}_{\mathrm{SD}}$ having comparatively high surface area regulated the slow release of urea-N more than that of $\mathrm{SRF}_{\mathrm{TW}}$. Kahn et al. (2008) impregnated $\mathrm{N}$ fertilizers into Oakwood charcoal using a vacuum rotary evaporator and obtained much slower $\mathrm{N}$ release in water. Coating urea granules using biochar-based copolymers, Chen et al. (2018) were able to reduce $\mathrm{N}$ release from urea to $65-69 \%$ by the end of 20 days in a soil medium. Though, these technologies can further improve controlled release of $\mathrm{N}$, the technology developed in this study is very simple and easily adoptable by farmers. However, Kottegoda et al. (2017) has produced a hydroxyapatite nano hybrid fertilizer with a similar releasing pattern observed in this study and found that they were able to reduce $\mathrm{N}$ application rate by $50 \%$ for paddy grown in an Alfisol in the Intermediate Zone of Sri Lanka.

\section{Effect of SRFs on N Nutrition and Growth of Rice Plants}

The SPAD meter readings increased with days after transplanting (DAT) from 20.3 at 7 DAT to 38.9 at 41 DAT in all treatments. In $\mathrm{N}$ added treatments, the SPAD readings were significantly higher $(p<0.05)$ than that of the control treatment throughout the growing period but it was not significantly different $(\mathrm{p}<0.05)$ among the urea and SRF treatments (Figure 3). The SPAD meter reading measures the greenness of the leaves which in turn highly correlate with the $\mathrm{N}$ concentration. Mahajan et al. (2014) has introduced critical levels for SPAD meter readings for the three most critical growth stages: tillering, panicle initiation and flowering, as 42.3, 43, and 41.7 respectively. For Sri Lankan varieties (BG300, 
BG357, BG2834, and BG2845) the levels are ranging within 38-42 (Weerakoon et al, 2002). In our study however, SPAD meter readings, at tillering (10 DAT) was 25-30, at panicle initiation (25 DAT) was 30-32 and at flowering (45DAT) 35-
40 , respectively in all treatments except no $\mathrm{N}$ treatment as it shows lower values than other. The critical SPAD reading could vary with growth stage, variety, and climatic conditions (Islam et al., 2009; Swain and Sandeep, 2010).

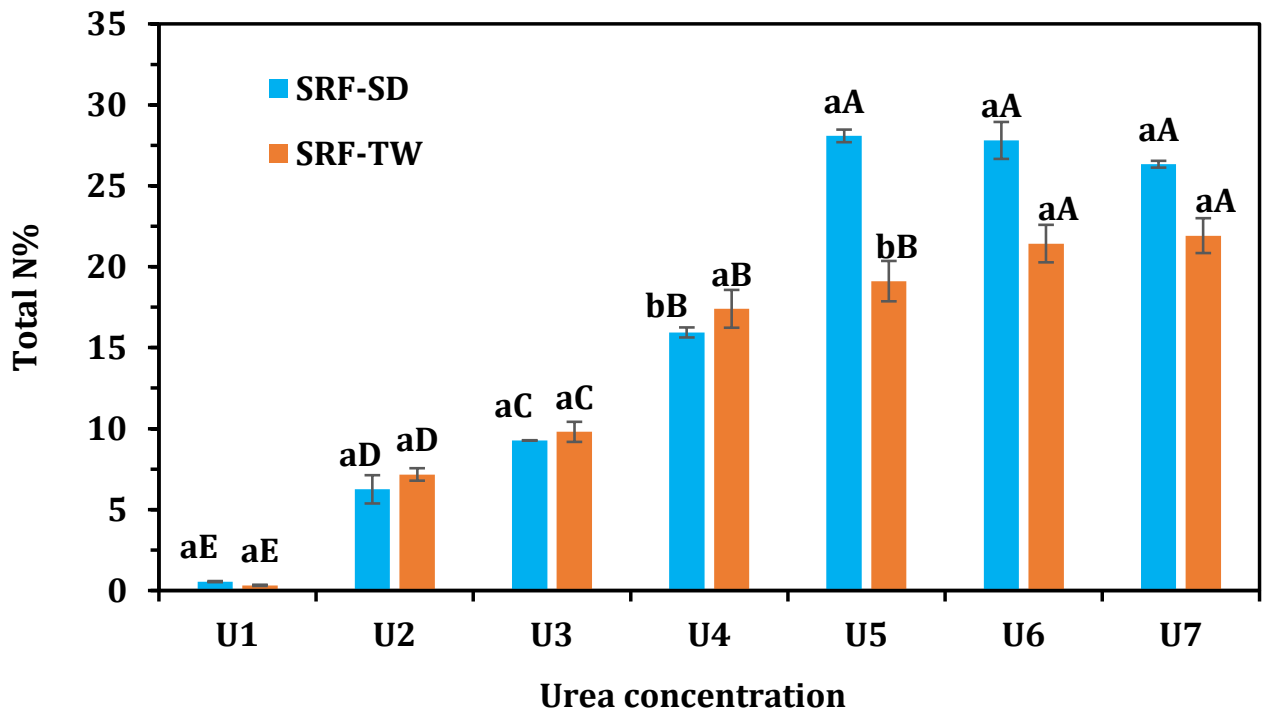

Figure 1: Variation in total $\mathrm{N} \%$ in the two urea-biochar composites with increasing urea concentrations in the solution from $0 \%$ (U1) to $100 \%$ (U7). Same lowercase letters at a given urea concentration and same uppercase letters for a given $S R F$ are not significantly different at $p<0.05$. Error bars on each bar indicates the $\pm \operatorname{SE}(n=3)$.

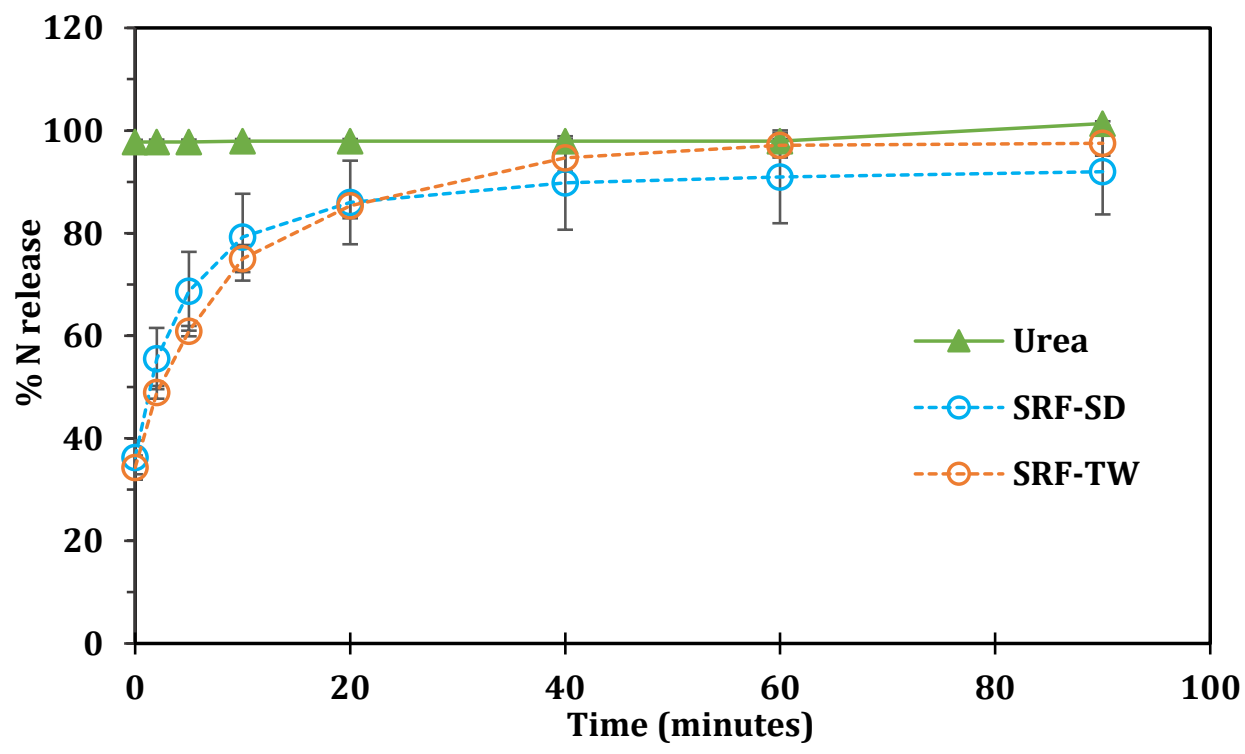

Figure 2: Percentages of intercalated $N$ released from $S R F S D, S R F_{T w}$ and urea- $N$ with time under the rapid water release test. Vertical bars on each data point are $\pm S E(n=3)$. 
Nutrient uptake by plants is governed by both growth rate of the plant and nutrient availability in soil (Plénet and Lemaire, 1999). Plants growing in treatments with $75-100 \% \mathrm{~N}$ have taken up significantly higher $\mathrm{N}$ content ( 85 to $124 \mathrm{mg} /$ plant) than by plant with zero $\mathrm{N}$ (43 $\mathrm{mg} / \mathrm{plant})$ due to higher growth and $\mathrm{N}$ availability (Table 1). Plant $\mathrm{N}$ uptake in $25 \% \mathrm{~N}$ cut down SRF treatments was not significantly different from $100 \%$ urea $\mathrm{N}$ treatment (Table 1) but the two SRF treatments had significantly different effects on plant $\mathrm{N}$ uptake where $\mathrm{SRF}_{\mathrm{SD}}$ recorded the highest $\mathrm{N}$ uptake (124 $\mathrm{mg} /$ plant).

Application of N at 75-100\% of recommended rates either as urea or SRF increased shoot dry matter accumulation by $72-110 \%$ when compared to no-N application (Table 1). Shoot dry matter contents in plants that received $75 \% \mathrm{~N}$ as SRF were not significantly different $(\mathrm{p}<0.05)$ from $100 \% \mathrm{~N}$ application as urea. The highest dry matter accumulation was observed in $75 \% \mathrm{~N}$ as $\mathrm{SRF}_{\mathrm{TW}}$ treatment and this was significantly higher than the treatment with $75 \% \mathrm{~N}$ as urea. Hundred grain weight also did not show any significant difference $(\mathrm{p}<0.05)$ among SRF treatments with $75 \% \mathrm{~N}$ and were comparable with the $100 \%$ urea treatment.

The ARN shows a significant increase $(\mathrm{p}<0.05)$ in $\mathrm{SRF}_{S D}$ treatment in comparison to all other treatments. The highest ARN (71\%) was in T4. The ARN of T5 $(60 \%)$ is not significantly different from the $100 \%$ urea treatment (52\%) and T2 (38\%) is significantly lower than them. The higher ARN can be due to the better synchronization of the available $\mathrm{N}$ and the plant $\mathrm{N}$ requirement. Therefore, $\mathrm{SRF}_{\mathrm{SD}}$ is having a better performance in supplying plant requirement of $\mathrm{N}$ although $25 \%$ of $\mathrm{N}$ supply was cut down from the DOA recommendation. The better performance of the $\mathrm{SRF}_{\mathrm{SD}}$ when compared to urea alone treatments could be related to the slow-release of $\mathrm{N}$ with time (Manikandan and Subramaniam, 2013). Application of biochar could also have contributed for the observed improvements by enhancing soil fertility (Laird et al., 2010; Lehmann, 2007).

\section{Effect on N Dynamics in Soil Solution}

Application of $100 \% \mathrm{~N}$ as urea has increased the soil solution $\mathrm{NH}_{4}{ }^{+}$concentration compared to other treatments (Figure 4). When 75\% N treatments are compared, it could be observed that a significantly higher $\mathrm{NH}_{4}{ }^{+}-\mathrm{N}$ levels were present in SRF treatments than that of $75 \%$ urea and no $\mathrm{N}$ treatments, particularly after two weeks of transplanting. Immediately after application of a urea granule to the soil, soil $\mathrm{pH}$ increases to around 9.0 closer to the granule surface (Sherlock et al, 1987).

Though this $\mathrm{pH}$ increment is temporary, it remains $2 \mathrm{pH}$ units higher in soil even after one week. But when applied as a slow-release source (N-butyl thiophosphoric triamide coated urea), less than 1 unit $\mathrm{pH}$ increment in soil had been observed (Santos et al., 2020). This pH increments causes N loss as ammonia (Rochette et al., 2013; Sahrawat, 2008). The lower values of $\mathrm{NH}_{4}{ }^{+}-\mathrm{N}$ concentration in pore waters of $75 \%$ urea applied soils compared to SRF treatments with similar $\mathrm{N}$ rates could be due to the loss of ammonium ions as gaseous ammonia. After 17 days of transplanting, the $\mathrm{NH}_{4}{ }^{+}$ concentrations in the soil solution decreased rapidly to very low levels by 29 days after transplanting and continued to be very low thereafter. This rapid decrease could be partly be due to increased growth rate during this period resulting a higher demand for $\mathrm{NH}_{4}{ }^{+}-\mathrm{N}$. Unlike the $\mathrm{NH}_{4}{ }^{+}$concentration, the $\mathrm{NO}_{3}{ }^{-}$concentrations in soil solution were not significantly different among treatments at different time after transplanting but it decreased rapidly from $20-25 \mathrm{mg} \mathrm{L}^{-1}$ at $10 \mathrm{DAT}$ to $10-18 \mathrm{mg} \mathrm{L}^{-1}$ by day 14 DAT (Figure 5). During the period after flowering (41 DAT), the $\mathrm{NO}_{3}^{-}-\mathrm{N}$ concentration in all treatments remained relatively constant with no statistically significant differences among treatments.

When urea is applied to a flooded soil it hydrolyzes to $\mathrm{NH}_{4}{ }^{+}$which in turn could be converted to $\mathrm{NO}_{3}^{-}$ depending on the oxidation status of the soil (Ponnamperuma, 1972). Since there was no leaching in the pot experiment, the removal of mineral $\mathrm{N}$ from the soil solution should be due to processes namely, plant uptake, immobilization, denitrification, and volatilization. Although rice plants prefer to uptake $\mathrm{N}$ as $\mathrm{NH}_{4}{ }^{+}$, rice roots are very efficient in absorbing and assimilating $\mathrm{NO}_{3}{ }^{-}$, and $\mathrm{NH}_{4}{ }^{+}$absorption and assimilation could also be stimulated by $\mathrm{NO}_{3}^{-}$(Kirk, 2001). Moreover, the $\mathrm{N}$ uptake of rice plants after panicle initiation, appeared to be determined more by $\mathrm{N}$ availability in soil solution than by demand for $\mathrm{N}$ and uptake ability of the crop and the amount of $\mathrm{N}$ taken up seemed to limit rice growth (Yamakawa et al., 2004). 


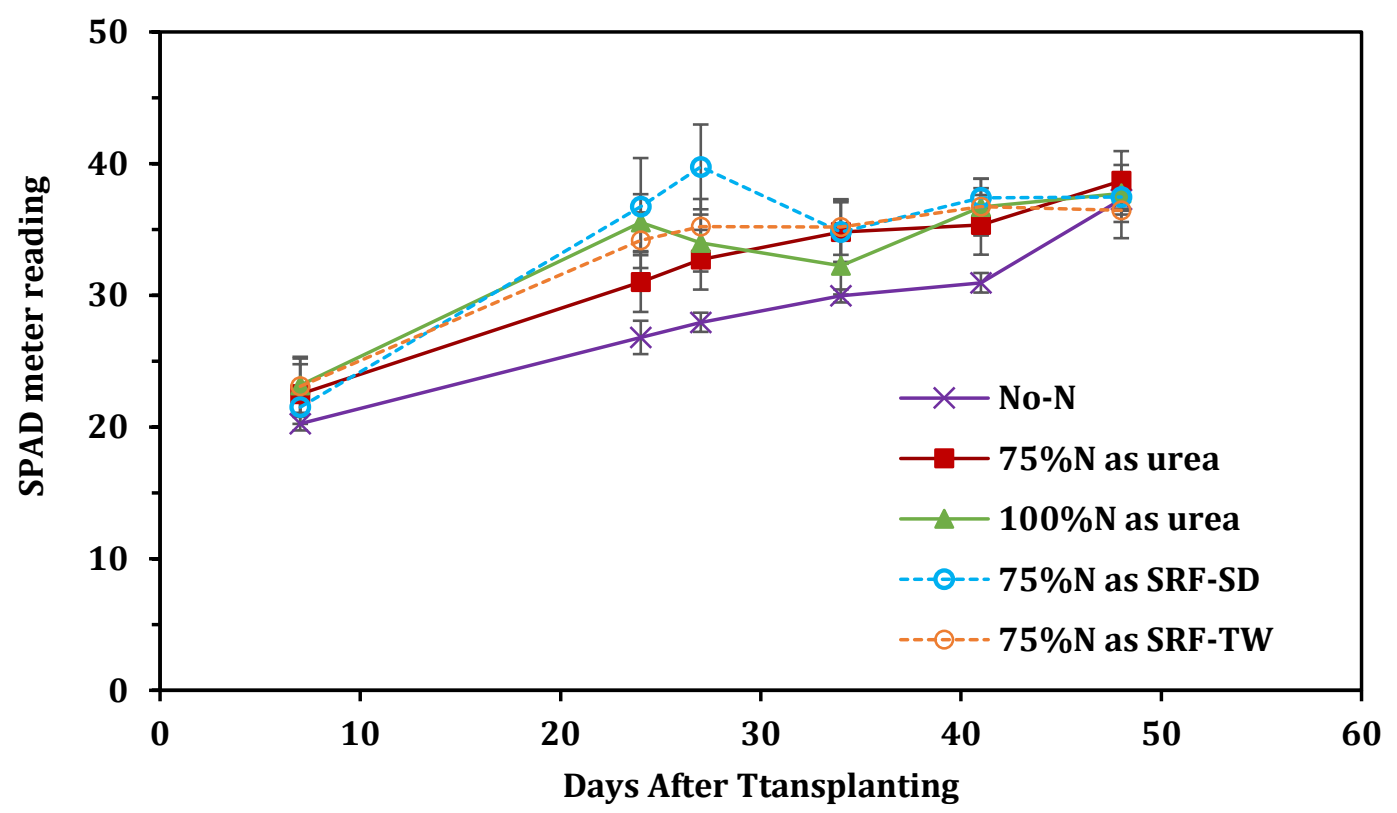

Figure 3: SPAD meter readings of the plants grown under each treatment with the days after transplanting. Vertical bars on each data point are $\pm S E(n=3)$.

Table 1: Mean dry matter production, $\mathrm{N}$ uptake, 100 grain weight and the agronomic efficiencies of each treatments $(n=3)$.

\begin{tabular}{lllll}
\hline Treatment & $\begin{array}{l}\text { Dry } \\
\text { (g/plant) }\end{array}$ & $\begin{array}{l}\text { Plant N uptake } \\
\text { (mg/plant) }\end{array}$ & $\begin{array}{l}\mathbf{1 0 0} \text { grain weight }^{\dagger} \\
\text { (g) }\end{array}$ & $\begin{array}{l}\text { ARN }^{\dagger} \\
\text { (\%) }\end{array}$ \\
\hline No-N (T1) & $5.14 \mathrm{c}$ & $42.46 \mathrm{~d}$ & $2.11 \mathrm{a}$ & - \\
$\mathbf{7 5 \%} \mathbf{N}$ as urea (T2) & $8.84 \mathrm{~b}$ & $85.48 \mathrm{c}$ & $1.98 \mathrm{a}$ & $37.9 \mathrm{c}$ \\
$\mathbf{1 0 0 \%} \mathbf{N}$ as urea (T3) & $10.53 \mathrm{ab}$ & $120.82 \mathrm{ab}$ & $1.98 \mathrm{a}$ & $51.7 \mathrm{~b}$ \\
$\mathbf{7 5 \%} \mathbf{N}$ as SRFSD(T4) & $9.59 \mathrm{ab}$ & $124.09 \mathrm{a}$ & $2.14 \mathrm{a}$ & $70.9 \mathrm{a}$ \\
$\mathbf{7 5 \%} \mathbf{N}$ as $\mathbf{S R F}_{\text {Tw(T5) }}$ & $10.80 \mathrm{a}$ & $110.38 \mathrm{bc}$ & $2.03 \mathrm{a}$ & $59.8 \mathrm{~b}$ \\
\hline
\end{tabular}

†Values followed by same letter within a column are not significantly different at $\mathrm{p}<0.05$.

According to Youngdahl et al. (1982) a $\mathrm{N}$ concentration of approximately $13 \mathrm{mg} \mathrm{L}^{-1}(900 \mu \mathrm{M})$ will support uptake between $90 \%$ and $100 \%$ of the maximum rate of either $\mathrm{N}$ ion species by 4- to 9 week-old rice plants. Okajima and Taniyama, (1980) reported that the minimum $\mathrm{NO}_{3}^{-}-\mathrm{N}$ concentration of the rhizosphere soil solution to give a maximum yield were $9.3-11.5 \mathrm{mg} \mathrm{L}^{-1}$. After about 30 days of transplanting, the main form of $\mathrm{N}$ in the soil solution was $\mathrm{NO}_{3}$ - in this experiment and ranged from $2-18 \mathrm{mg} \mathrm{N} \mathrm{L}^{-1}$ among treatments without any significant treatment effect. Therefore, the observed differences in plant growth of different treatments could be attributed to the variation in $\mathrm{NH}_{4}{ }^{+} \mathrm{N}$ concentration during the late vegetative period. The decrease in $\mathrm{NH}_{4}{ }^{+} \mathrm{N}$ levels in the pore water could be due to plant uptake of ammonium. Rice plants prefer take up $\mathrm{N}$ as ammonium to nitrate. However, the high dry matter production $(\sim 10 \mathrm{~g} /$ plant $)$ and plant uptake of $\mathrm{N}(\sim 100 \mathrm{mg} /$ plant $)$ can be observed in all fertilized treatments. 


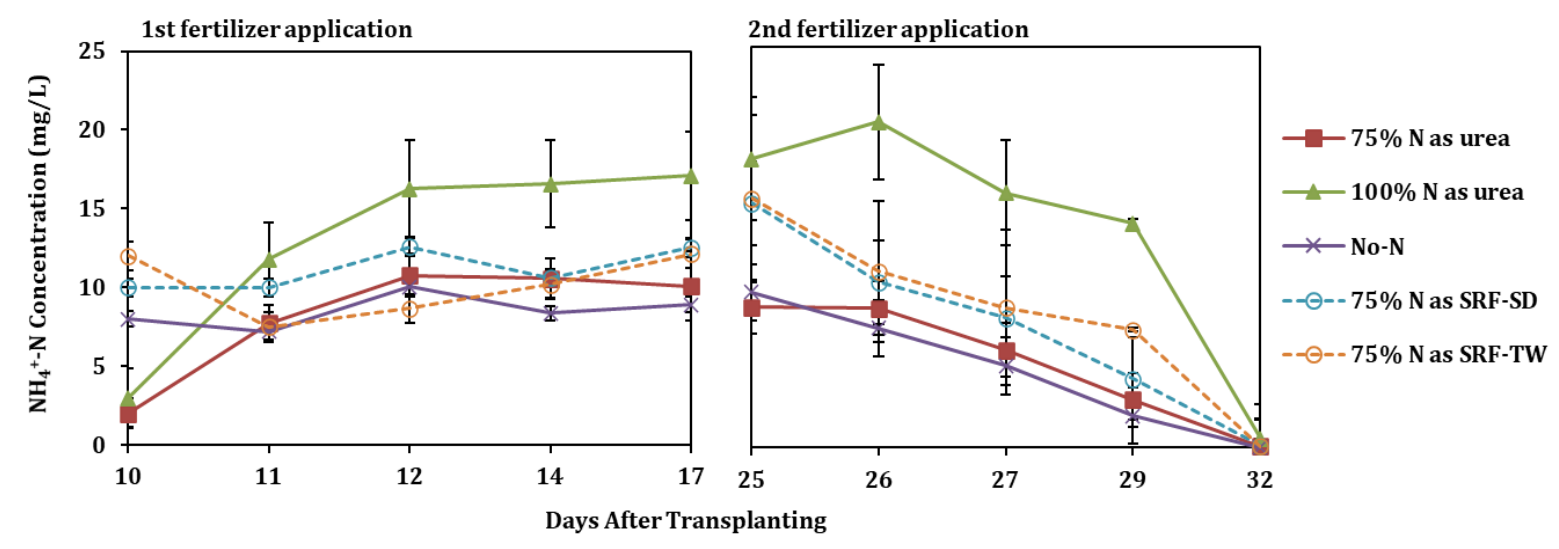

Figure 4: Variation in $\mathrm{NH}^{+}-\mathrm{N}$ concentration of the pore water in different treatments with days after transplanting. Vertical bars at each data point are $\pm S E(n=3)$.

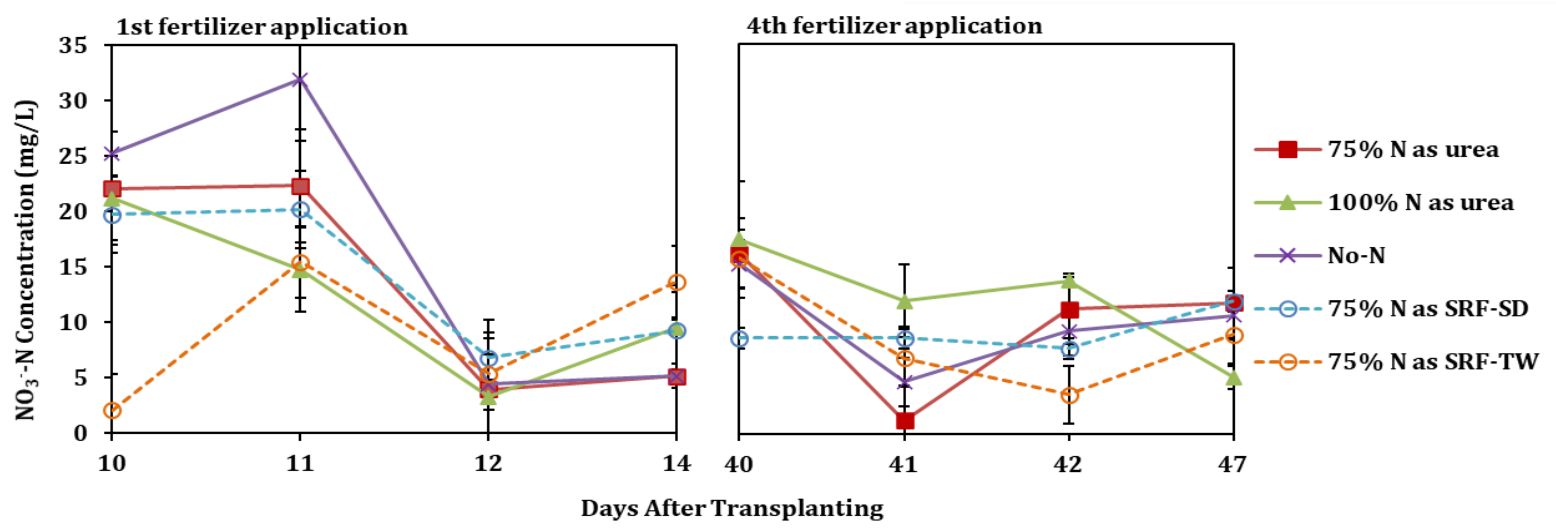

Figure 5: Variation in $\mathrm{NO}_{3}-\mathrm{N}$ concentration of the pore water in different treatments with days after transplanting. Vertical bars at each data point are $\pm S E(n=3)$.

Comparatively higher soil solution $\mathrm{N}$ levels in the $\mathrm{SRF}_{\mathrm{SD}}$ when compared to that of $\mathrm{SRF}_{\mathrm{TW}}$ could be due to the differences in pore structure and surface properties related releasing patterns of urea nitrogen between the two biochar types. When nitrogen is released slowly from the urea-BC composite, there is a better synchrony between the nitrogen availability and plant $\mathrm{N}$ requirement resulting a high $\mathrm{N}$ uptake and low susceptibility for losses (Manikandan and Subramaniam, 2013). This was evident in the ARN data in $\mathrm{SRF}_{\mathrm{SD}}$.

\section{CONCLUSION}

From the two biochar types used in this study, the saw dust biochar is having a higher potential than tea waste biochar to intercalate urea. Maximum intercalation of urea into biochar through the capillary action could be obtained when the urea concentration in the solution at U5 or U6 level. Increasing the urea concentration further up to $100 \%$ will increase wastage of urea. The produced ureasaw dust BC composites had 29\% N while urea- tea waste BC composite had $22 \% \mathrm{~N}$. The SRFs produced using these urea-BC composites found to be effective in maintaining $\mathrm{N}$ concentrations in soil solution and in plants that are comparable to $100 \%$ urea application when they were applied at $75 \%$ recommended $\mathrm{N}$ levels. Reduced application $(75 \% \mathrm{~N})$ of $\mathrm{N}$ as SRF have similar effects on growth of rice plants in comparison to the $100 \% \mathrm{~N}$ recommendation. The $\mathrm{SRF}_{\mathrm{SD}}$ provided higher $\mathrm{N}$ recovery efficiency in paddy soil than that of inorganic urea fertilizer under the conditions tested in this study. Although results of the pot experiment are 
encouraging, further evaluating these slowrelease urea fertilizers under different rice growing environments with different varieties over long period under field condition is essential in future studies to realize maximum potential of this new technology.

\section{REFERENCES}

Akgül, G., Ateş, A., Yaşar, G. and Hatipoğlu, H. (2017). Production and characterisation of biochar from tea waste and its nickel removal capacity from aqueous solutions. Progress in Industrial Ecology. 11(2), 105-117.

Akgül, G., Maden, T.B., Diaz, E. and Jiménez, E.M. (2018). Modification of tea biochar with $\mathrm{Mg}$, $\mathrm{Fe}, \mathrm{Mn}$ and $\mathrm{Al}$ salts for efficient sorption of $\mathrm{PO}_{4}^{3-}$ and $\mathrm{Cd}^{2+}$ from aqueous solutions. Journal of Water Reuse and Desalination. 6, 57-66.

Ashworth, A.J., Sadaka, S.S., Allen, F.L., Sharara, M.A. and Keyser, P.D. (2014). Influence of pyrolysis temperature and production conditions on switchgrass biochar for use as a soil amendment. BioResources, 9(4), 7622-7635.

Bockman, O.C., and Olfs, H.W. (1998). Fertilizers, agronomy and $\mathrm{N}_{2} \mathrm{O}$. Nutrient Cycling in Agroecosystems. 52, 165-170.

Bremner, J.M. (1965). Total nitrogen. pp. 11491178. In: C.A. Black, D.D. Evans, J.L. White, L.E. Ensminger, and F.E. Clark (Eds.) Methods of Soil Analysis. Part 2. Chemical and Microbiological Properties. American Society of Agronomy, Madison, WI.

Chen, L., Chen, Q., Rao, P., Yan, L., Shakib, A. and Shen, G. (2018). Formulating and optimizing a novel biochar-based fertilizer for simultaneous slow-release of nitrogen and immobilization of cadmium. Sustainability. 10(8), 2740. https://doi.org/10.3390/su10082740

\section{ACKNOWLEDGMENT}

National Research Council of Sri Lanka is acknowledged for funding this study (NRC/TO/16-07)

Chen, S., Yang, M., Ba, C., Yu, S., Jiang, Y., Zou, H., and Zhang, Y. (2018). Preparation and characterization of slow-release fertilizer encapsulated by biochar-based waterborne copolymers. Science of the Total Environment. 615, 431-437.

Chunxue, Y., Joseph, S., Lianqing, L.I., Genxing, P.A.N., Yun, L.I.N., Munroe, P., Ben, P.A.C.E., Taherymoosavi, S., Van Zwieten, L., Thomas, T. and Nielsen, S. (2015). Developing more effective enhanced biochar fertilisers for improvement of pepper yield and quality. Pedosphere. 25(5), 703-712.

Clark, M., Hastings, M. G., and Ryals, R. (2019). Soil carbon and nitrogen nynamics in two agricultural soils amended with manurederived biochar. Journal of Environmental Quality, 48(3), 727-734..

Cui, L., Li, L., Zhang, A., Pan, G., Bao, D. and Chang, A. (2011). Biochar amendment greatly reduces rice $\mathrm{Cd}$ uptake in a contaminated paddy soil: a two-year field experiment. BioResources. 6(3), 26052618.

De Carvalho, T.A., Puga, A.P., Pires, A.M.M., Ligo, M. and de Andrade, C.A., (2019). Residual effect of nitrogen fertilizers formulated with biochar. Horticulture International Journal. 3(6), 315-318.

Dharmakeerthi, R.S., Chandrasiri, J.A.S. and Edirimanne, V.U. (2012). Effect of rubber wood biochar on nutrition and growth of nursery plants of Hevea brasiliensis established in an Ultisol. SpringerPlus. 1(1), 84. 
Dimin, M.F., Se, S.M., Shaaban, A. and Hashim, M.M. (2014). Urea impregnated biochar to minimize nutrients loss in paddy soils. International Journal of Automotive \& Mechanical Engineering. 10, 2016-2024.

Enders, A., Hanley, K., Whitman, T., Joseph, S. and Lehmann, J. (2012). Characterization of biochars to evaluate recalcitrance and agronomic performance. Bioresource technology. 114, 644-653.

Fageria, N.K. and Baligar, V.C. (2003). Methodology for Evaluation of Lowland Rice Genotypes for Nitrogen Use Efficiency. Journal of Plant Nutrition, 26, 1315-1333.

Gamage, D.A.S. , Basnayake ,B.F.A., Costa, W.A.J.M., Vidanagamage, K.E.W. (2012), Evaluation of total N,P, K and organic matter contents of soil amended with paddy husk charcoal coated urea and comparison of the yield of paddy production. In $2^{\text {nd }}$ International Conference on Sustainable Built Environment, 14th-16th December 2012. Kandy, Sri Lanka.

Ghani, W.A.W.A.K. and Silva, G. (2014). Sawdust-Derived Biochar: Characterization and $\mathrm{CO}_{2}$ Adsorption/Desorption Study. Journal of Applied Sciences, 14(13), 1450-4.

González, M.E., Cea, M., Medina, J., González, A., Diez, M.C., Cartes, P., Monreal, C. and Navia, R. (2015). Evaluation of biodegradable polymers as encapsulating agents for the development of a urea controlled-release fertilizer using biochar as support material. Science of the Total Environment. 505, 446453.

Gray, M., Johnson, M.G., Dragila, M.I. and Kleber, M. (2014). Water uptake in biochars, the roles of porosity and hydrophobicity. Biomass and Bioenergy. 61, 196-205.

He, H., Tam, N.F., Yao, A., Qiu, R., Li, W.C. and Ye, Z. (2017). Growth and Cd uptake by rice (Oryza sativa) in acidic and Cdcontaminated paddy soils amended with steel slag. Chemosphere. 189, 247-254.
Huang, M., Fan, L., Chen, J., Jiang, L. and Zou, Y. (2018). Continuous applications of biochar to rice: Effects on nitrogen uptake and utilization. Scientific Reports, 8(1), 1-9.

Islam, M. S., Bhuiya, M. S. U., Rahman, S., \& Hussain, M. M. (2009). Evaluation of SPAD and LCC based nitrogen management in rice (Oryza sativa L.). Bangladesh Journal of Agricultural Research, 34(4), 661-672.

Joshua, J.A., Ahiekpor, J.C. and Kuye, A. (2016). Nigerian hardwood (Nesogordonia papaverifera) sawdust characterization: Proximate analysis, cellulose and lignin contents. Lignocellulose, 5(1), 50-58.

Keech, O., Carcaillet, C. and Nilsson, M.C. (2005). Adsorption of allelopathic compounds by wood-derived charcoal: the role of wood porosity. Plant and Soil, 272(12), 291-300.

Khan, M.A., Kim, K.W., Mingzhi, W., Lim, B.K., Lee, W.H., \& Lee, J.Y. (2008). Nutrientimpregnated charcoal: an environmentally friendly slow-release fertilizer. The Environmentalist, 28(3), 231-235.

Kim, J., Yoo, G., Kim, D., Ding, W. and Kang, H., (2017). Combined application of biochar and slow-release fertilizer reduces methane emission but enhances rice yield by different mechanisms. Applied Soil Ecology, 117, 57-62.

Kirk, G.J.D., (2001). Plant-mediated processess to acquire nutrients: nitrogen uptake by rice plants. Plant and Soil, 232(1-2), 129-134.

Kottegoda, N., Sandaruwan, C., Priyadarshana, G., Siriwardhana, A., Rathnayake, U.A., Berugoda Arachchige, D.M., Kumarasinghe, A.R., Dahanayake, D., Karunaratne, V. and Amaratunga, G.A. (2017). Ureahydroxyapatite nanohybrids for slow release of nitrogen. ACS nano. 11, 12141221.

Laird, D.A.P., Fleming, D.D. Davis, R. Horton, Wang B. and Karlen, D.L. (2010). Impact of biochar amendments on the quality of a 
typical Midwestern agricultural soil. Geoderma. 158, 443-449.

Lehmann, J. (2007). Bio-energy in the black. Frontiers in Ecology and the Environment. 5, 381-387.

Mahajan, G.R., Pandey, R.N., Kumar, D., Datta, S.C., Sahoo, R.N. and Parsad, R. (2014). Development of critical values for the leaf color chart, SPAD and FieldScout CM 1000 for fixed time adjustable nitrogen management in aromatic hybrid rice (Oryza sativa L.). Communications in Soil Science and Plant Analysis, 45(14), 1877-1893.

Manikandan, A. and Subramanian, K.S. (2013). Urea intercalated biochar-a slow release fertilizer production and characterization. Indian Journal of Science and Technology. 6, 5579-5584.

Markus, D.K., McKinnon, J.P. and Buccafuri, A.F. (1985). Automated Analysis of Nitrite, Nitrate, and Ammonium Nitrogen in Soils. Soil Science Society of America Journal. 49, 1208-1215.

Melich, A. (1984). Melich3 soil test extractant: a modification of Mehlich2 extractant. Communications of Soil and Plant Analysis. $15,1409-1416$.

Montemurro, F. and Diacono, M. (2016). Towards a better understanding of agronomic efficiency of nitrogen: assessment and improvement strategies. Agronomy. 6, 31.

Munasinghe, S.T., Dharmakeerthi, R.S., Weerasinghe, P. and Madusanka, L. (2018) Preparation of biochar as a soil amendment from rice husk and corn cob by slow pyrolysis process. Tropical Agriculturist. 166(2),137-151.

Murphy, J. and Riley, J. (1962). A modified single solution method for the determination of phosphate in natural waters. Analytica Chimica Acta, 27, 31-36.
Okajima, H. and Taniyama, I., (1980). Significance of mass flow in nitrate-nitrogen supply to plant roots. Soil Science and Plant Nutrition, 26(3), 363-374.

Olsen, S.R., and Sommers, L.E. (1982). Phosphorus pp.403-430. In: A.L. Page et al., (Eds). Methods of Soil Analysis, Part 2 Chemical and Microbiological Properties. American Society of Agronomy, Madison, WI.

Peoples M.B., Freney J.R., and Moiser A.R. (1995) Minimizing gaseous losses of nitrogen. pp. 565-601. In: P.E. Bacon (Ed.) Nitrogen Fertilization in the Environment. Marcel Dekeker Inc. New York.

Plénet, D. and Lemaire, G. (1999). Relationships between dynamics of nitrogen uptake and dry matter accumulation in maize crops. Determination of critical N concentration. Plant and Soil. 216(1-2), 6582.

Ponnamperuma, F.N. (1972). The chemistry of submerged soils. Advances in Agronomy, $24,29-96$.

Rochette, P., Angers, D.A., Chantigny, M.H., Gasser, M.O., MacDonald, J.D., Pelster, D.E. and Bertrand, N. (2013). NH3 volatilization, soil concentration and soil $\mathrm{pH}$ following subsurface banding of urea at increasing rates. Canadian Journal of Soil Science. 93, 261-268.

Rose, M.T., Perkins, E.L., Saha, B.K., Tang, E.C., Cavagnaro, T.R., Jackson, W.R., Hapgood, K.P., Hoadley, A.F. and Patti, A.F. (2016). A slow release nitrogen fertiliser produced by simultaneous granulation and superheated steam drying of urea with brown coal. Chemical and Biological Technologies in Agriculture, 3(1), 10.

Sahrawat, K.L. (2008). Factors affecting nitrification in soils. Communications in Soil Science and Plant Analysis. 39, 1436-1446.

Santos, C. F., da Silva Aragão, O. O., Silva, D. R. G., da Conceição Jesus, E., Chagas, W. F. T., 
Correia, P. S., and de Souza Moreira, F. M. (2020). Environmentally friendly urea produced from the association of $\mathrm{N}-(\mathrm{n}$ butyl) thiophosphoric triamide with biodegradable polymer coating obtained from a soybean processing byproduct. Journal of Cleaner Production, 276, 123014.

Shaviv, A. (2000). Advances in controlled release of fertilizers. Advances in Agronomy. 71, 1-49.

Sherlock, R.R., Black, A.S. and Smith, N.P., (1987). Microenvironment and soil $\mathrm{pH}$ around broadcast urea granules and its relationship to ammonia volatilization. $\mathrm{p}$. 316-326. In: P.E. Bacon, J. Evans, R.R. Storrier, and A.C. Taylor (Eds.) Nitrogen Cycling in Temperate Agricultural Systems. Australian Society of Soil Science.

Weerakoon, W.M.W., Ranathunge, R.A.N.D. Sirisena, D.N., and Wickramasinghe, W.M.A.D.B. (2002) Determining nitrogen response of rice through chlorophyl meter technique. Annals of the Sri Lanka Department of Agriculture. 4, 424-428.

Sirisena, D.N., Wickramasinghe, W.M.A.D.B., Weerakoon, W.M.W., Kumaragamage, D. and Bandara, S.T. (2013). Evaluation of the leaf-N based nitrogen fertilizer management in irrigated transplanted rice. Annals of Sri Lanka Department of Agriculture. 15, 233-241.

Swain, D.K., and Sandip, S.J. (2010). Development of SPAD values of mediumand long-duration rice variety for site- specific nitrogen management. Journal of Agronomy, 9(2), 38-44.

United Nations, (2019). Colombo Declaration on Sustainable Nitrogen Management. United Nations Global Campaign on Sustainable Nitrogen Management https://www.unenvironment.org/newsand-stories/press-release/colombodeclaration-calls-tackling-global-nitrogenchallenge.

Watkins, D., Nuruddin, M., Hosur, M., TcherbiNarteh, A. and Jeelani, S. (2015). Extraction and characterization of lignin from different biomass resources. Journal of Materials Research and Technology. 4(1), 26-32.

Yamakawa, Y., Saigusa, M., Okada, M. and Kobayashi, K. (2004). Nutrient uptake by rice and soil solution composition under atmospheric $\mathrm{CO}_{2}$ enrichment. Plant and Soil. 259(1-2), 367-372.

Yin, D., Wang, X., Chen, C., Peng, B., Tan, C. and Li, H. (2016). Varying effect of biochar on $\mathrm{Cd}, \mathrm{Pb}$ and As mobility in a multi-metal contaminated paddy soil. Chemosphere. 152, 196-206.

Yoo, G., Lee, Y.O., Won, T.J., Hyun, J.G. and Ding, W. (2018). Variable effects of biochar application to soils on nitrificationmediated $\mathrm{N}_{2} \mathrm{O}$ emissions. Science of the Total Environment. 626, 603-611.

Youngdahl, L.J., Pacheco, R., Street, J.J. and Vlek, P.L.G. (1982). The kinetics of ammonium and nitrate uptake by young rice plants. Plant and Soil. 69(2), 225-232. 